\title{
FALLS AND FUNCTIONAL CAPACITY IN THE OLDEST OLD DWELLING IN THE COMMUNITY
}

\author{
Thaís Alves Brito ${ }^{1}$, Marcos Henrique Fernandes'ㄹ, Raildo da Silva Coqueiro ${ }^{3}$, Cleber Souza de Jesus ${ }^{4}$
}

\footnotetext{
${ }^{1}$ Master in Nursing and Health. Professor of the Department of Health at Universidade Estadual do Sudoeste da Bahia (UESB). Bahia, Brazil. E-mail: thaisbrito03@yahoo.com.br

${ }^{2}$ Ph.D. in Health Sciences. Professor of the Health Department and the Graduate Program in Nursing and Health at UESB. Bahia, Brazil. E-mail: marcoshenriquefernandes@bol.com.br

${ }^{3}$ Master in Physical Education. Professor of the Health Department at UESB. Bahia, Brazil. E-mail: rscoqueiro@uesb.edu.br

${ }^{4}$ Doctoral Student of the Graduate Program in Collective Health at Universidade Federal da Bahia. Professor of the Health Department at UESB. Bahia, Brazil. E-mail: csjesus@uesb.edu.br
}

\begin{abstract}
The aim was to verify the association between falls and functional capacity in the oldest old dwelling in the community. This is a community-based cross-sectional study. The population was comprised of elderly citizens aged greater than 80 years, residing in the urban area of Lafaiete Coutinho, in the state of Bahia, Brazil. Data collection was carried out in January of 2011. It was based on home life, using a questionnaire capturing sociodemographic data, fall occurrences and functional capacity utilizing the Katz scale. Data analysis was done through Poisson regression, adopting a significance level of $5 \%$. Ninety-four elderly citizens were interviewed, with an average age of 86.1 years $( \pm 6,39) ; 59.6 \%$ of the participants were female. The fall prevalence was $27.7 \%$ and $19.6 \%$ of the participants were classified as dependent for activities of daily living. A strong association was identified between falls and functional activities $(\mathrm{RP}=2.08 ; 1.17$ - 3.70). Results showed a significantly higher proportion of falls among the functionally dependent oldest old than among the independent elderly.
\end{abstract}

DESCRIPTORS: Accidental falls. Aged. Aged, 80 and over. Activities of daily living.

\section{QUEDAS E CAPACIDADE FUNCIONAL EM IDOSOS LONGEVOS RESIDENTES EM COMUNIDADE}

\begin{abstract}
RESUMO: O objetivo foi verificar associação entre quedas e capacidade funcional em idosos longevos residentes em comunidade. Trata-se de estudo transversal de base comunitária. A população foi composta por idosos com idade $\geq 80$ anos, moradores da zona urbana do município de Lafaiete Coutinho-BA, Brasil. A coleta de dados, realizada em janeiro de 2011, foi domiciliar, através de questionário com informações sociodemográficas, ocorrência de quedas e capacidade funcional, pela escala de Katz. Realizou-se análise dos dados por regressão de Poisson, adotando-se nível de significância de 5\%. Foram entrevistados 94 idosos, com média de 86,1 anos $( \pm 6,39)$, sendo $59,6 \%$ do sexo feminino. A prevalência de quedas foi de $27,7 \%$ e foram classificados como dependentes para Atividades básicas da vida diária, $19,6 \%$ dos idosos. Identificou-se forte associação entre quedas e capacidade funcional (RP=2,08; 1,17 - 3,70). Os resultados mostraram proporção de quedas significativamente maior entre idosos longevos funcionalmente dependentes do que entre idosos independentes.
\end{abstract}

DESCRITORES: Acidentes por quedas. Idoso. Idoso de 80 anos ou mais. Atividades cotidianas.

\section{CAÍDAS Y CAPACIDAD FUNCIONAL EN ANCIANOS LONGEVOS RESIDENTES EN LA COMUNIDAD}

\begin{abstract}
RESUMEN: El objetivo fue verificar asociación entre caídas y capacidad funcional en ancianos residentes en la comunidad. Se trata de estudio transversal de base comunitaria. La populación fue compuesta por mayores con edad $\geq 80$ años, habitantes de zona urbana del municipio de Lafaiete Coutinho-BA, Brasil. La colecta de datos, enero de 2011, fue domiciliar através de cuestionario con informaciones socio-demográficas, ocurrencia de caídas y capacidad funcional por Katz. El análisis de datos fue realizado a partir de regresión de Poisson adoptándose nivel de significancia de $5 \%$. Fueron entrevistados 94 mayores con media de 86,1 años ( $\pm 6,39)$, siendo 59,6\% de sexo femenino. La prevalencia de caídas fue $27,7 \%$ y fueron clasificados como dependientes para Actividades de vida diária $19,6 \%$ de ancianos. Se identificó fuerte asociación entre caídas y capacidad funcional ( $\mathrm{RP}=2,08 ; 1,17-3,70)$. Los resultados sugieren que proporción de caídas es significativamente mayor entre los ancianos funcionalmente dependientes que entre mayores independientes.
\end{abstract}

DESCRIPTORES: Accidentes por caídas. Anciano. Anciano de 80 o más años. Actividades cotidianas. 


\section{INTRODUCTION}

Population aging is a reality in most countries, becoming a relevant theme from scientific and public policy perspectives, mobilizing and calling the attention of researchers and social policy promoters regarding the challenges that this process is presenting to societies.

The increase in life expectancy is a worldwide phenomenon, and the age group with the fastest growth is the group including individuals who are 80 years of age or older. In Brazil, while the average yearly geometric growth rate of the general elderly population ( $\geq 60$ years) is approximately $3.3 \%$, the rate among the oldest segment of that group is $5.4 \%$, one of the world's highest. ${ }^{1}$

The increase in this group of elderly individuals brings to light a discussion regarding incapacitating events in that age group, among which the occurrence of falls is notable. Falls are very well-known and feared by most seniors due to consequences such as fractures, activity restriction, health decline and the risk of institutionalization. ${ }^{2-4}$

Falls can be defined as an involuntary body displacement to a lower level in relation to the initial position, with the inability to correct this position change in a timely fashion, determined by multifactoral circumstances which undermine stability. ${ }^{5}$ Falls can be grouped according to intrinsic and extrinsic factors. Among the former are physiological changes related to aging, illness and the effects caused by drugs; among the latter, factors that depend on social and environmental circumstances that represent challenges to the elderly are included. ${ }^{6}$

Thus, the concept of health for this population group cannot be based solely on the parameters of complete physical, psychic and social well-being professed by the World Health Organization, but should also be guided by the standard of functional capacity proposed by the National Health Policy for the Elderly Person (NHPEP). Maintaining independence and autonomy for the longest possible time are goals to be attained in health care for the elderly.?

The physiological changes which the elderly experience progressively interfere with their functional capacity, with Activities of Daily Living (ADLs) being used as frequent measures for this evaluation. ADLs consist of self care practices, such as showering, dressing and feeding. In general, a higher number of difficulties in performing ADLs equal a more severe incapacity.

The compromise of functional capacity in the elderly has important implications for the family, the community, the healthcare system and for the their own lives, since incapacity results in higher vulnerability and dependency, contributing to a decrease in well-being and quality of life for the elderly. ${ }^{8}$

In Brazil, few studies approach falls and their determinants among the communitydwelling population of the oldest old (80 years or over). This highlights the interest in the study of falls, health and its multiple dimensions for this population, which has been proportionately growing and, in a much faster way, changing the age composition within its own group. The relevance of the present study, concerning senior citizens observed in their daily lives and home environments, is a needed addition to research in this area, since this is the reality for most of Brazil's senior citizens. Therefore, there is a need for investigations that can contribute to the fulfillment of these knowledge gaps.

In this context, the objective of this study was to verify the association between falls and functional capacity in the oldest old dwelling in the community.

\section{MATERIALS AND METHODS}

This study is a cross-sectional research, based on a specific population and community, titled "Nutritional state, risk behaviors and health conditions in the elderly of Lafaiete Coutinho, Bahia". The municipality had, at the time of data collection, a population of 4,162 , with the number of oldest old totaling 3.1\% (131). Lafaiete Coutinho has low sociodemographic and educational indicators, a fact that can be observed in its population's low education and socioeconomic conditions.

A census was conducted in January of 2011, based on the list of seniors registered in the Family Health Strategy (FHS), which covers $100 \%$ of the population of the referred city, aiming to identify all persons 80 years of age or over who were non-institutionalized and residing in the urban area. Thus, out of the 131 senior citizens identified, 31 lived in the rural area, four refused to participate and two weren't found at 
their homes after three visits on alternating days. Therefore, the study population consisted of 94 senior citizens.

An appropriate questionnaire was used, derived from the questionnaire used in the Health, Wellbeing and Ageing Research (HWBAr) conducted in seven countries in Latin America and the Caribbean. ${ }^{9}$ The Brazilian version of the International Questionnaire of Physical Activities (IQPA) form (long version) ${ }^{10}$ was added to it in order to evaluate the level of physical activity. A pilot study was carried out in a neighboring city by a previously trained team, which made it possible to test the research instrument and adjust it.

Before beginning the interview, cognitive screening was conducted through a modified and validated version of the Mini Mental State Exam, aiming to evaluate the retention of recent memory and the ability to answer the proposed questions. ${ }^{11}$ The adopted cut-off score was $\geq$ 13 points (non-compromised) and $\leq 12$ points (compromised).

For the seniors who achieved a score equal to or less than 12 points, the research proceeded with the aid of a communicant. Communicants were defined as persons living in the same home who were able to offer information about the interviewed senior. The communicant completed the Pfeffer Functional Activities questionnaire, being interviewed when the questionnaire score was six or greater, and was completed with the senior if the score was five or less. ${ }^{12}$

Information regarding falls (the dependent variable) was obtained from the question "Have you suffered any falls in the last 12 months? (yes or no)". Functional capacity (the independent variable) was measured using the scale that evaluates ADLs, including self-care activities such as feeding, bathing, dressing, grooming, mobility and toileting. ${ }^{13}$ The ADL variable was dichotomized, using a cut-off point of $4 / 5$; thus 14 of the elderly with a score of 4 or under were considered independent for ADLs and all of the elderly with a score greater than 4 were considered dependent.

The explored sociodemographic variables were: gender; ability to write a note (yes or no); family income per capita divided into three levels $(\leq \mathrm{R} \$ 255, \leq \mathrm{R} \$ 510$ and $>\mathrm{R} \$ 510)$; marital status (in a stable union or not); and participation in religious activities (yes or no), analyzed by the identification of some type of religion.

Subjects were considered as insufficiently active if they participated in less than 150 minutes of moderate of vigorous physical activity per week. ${ }^{15}$ Regarding the number of chronic diseases, the elderly were questioned as to whether or not any health professional had ever diagnosed them with any of these diseases: hypertension, diabetes, osteoporosis, cancer, lung disease, heart or circulatory disease and arthritis/arthrosis. Afterwards, they were categorized as having none; one; or two or more chronic diseases.

A descriptive analysis of the variables was carried out, calculating the absolute and relative frequencies, as well as the average and standard deviation. Following that, as association measures, a prevalence ratio (PR) and confidence interval at $95 \%$ (CI95\%) were estimated from Poisson regression, with robust variance and time under risk of 1 for each individual. ${ }^{16}$ The adjustment variables that showed a significance of at least $20 \%$ $(p \leq 0.20)$ in rough analysis were included in the multiple analysis. The system's best adjustment was assessed from the Hosmer-Lemeshow test (goodness-of-fit).

Data was charted and analyzed using the Statistical Package for Social Sciences - SPSS for Microsoft Windows (SPSS. 15.0). In this study the significance level was fixed at $5 \%$.

The study protocol was approved by the University of Southwestern Bahia Research Ethics Committee ( $\left.n^{\circ} 064 / 2010\right)$. Participation was voluntary and all subjects signed an informed consent.

\section{RESULTS}

The study population consisted of 56 women (59.6\%) and 38 men (40.4\%). The average age was 86.1 years $(\mathrm{SD}=6.39)$, with the highest age being 105 years. Table 1 shows the seniors' distribution according to sociodemographic variables, health conditions and behavioral factors. $19.6 \%$ of the elderly were classified as dependent for activities of daily living (ADLs). Figure 1 shows the prevalence of falls in the oldest old. 
Table 1 - Descriptive characteristics of the oldest old. Lafaiete Coutinho-Bahia, Brazil, 2011

\begin{tabular}{|c|c|c|c|}
\hline Variables & \%Answer & $\mathbf{n}$ & $\%$ \\
\hline Gender & 100 & & \\
\hline Female & & 56 & 59.6 \\
\hline Male & & 38 & 40.4 \\
\hline Literate & 100 & & \\
\hline Yes & & 20 & 21.3 \\
\hline No & & 74 & 78.7 \\
\hline Marital status & 100 & & \\
\hline In a stable union & & 42 & 44.7 \\
\hline Not in a stable union & & 52 & 55.3 \\
\hline Per capita income $(\mathbf{R} \$)$ & 93.6 & & \\
\hline$\leq 255.00$ & & 39 & 44.3 \\
\hline $255.00-510.00$ & & 37 & 42 \\
\hline$>510.00$ & & 12 & 13.6 \\
\hline Participation in religious activities & 97.9 & & \\
\hline Yes & & 87 & 94.6 \\
\hline No & & 5 & 5.4 \\
\hline Physical activity & 97.9 & & \\
\hline Active & & 24 & 26.1 \\
\hline Insufficiently active & & 68 & 73.9 \\
\hline Number of chronic diseases & 98.9 & & \\
\hline None & & 15 & 16.1 \\
\hline One & & 30 & 32.3 \\
\hline Two or more & & 48 & 51.6 \\
\hline ADLs* $^{*}$ & 97.9 & & \\
\hline Independent & & 74 & 80.4 \\
\hline Dependent & & 18 & 19.6 \\
\hline
\end{tabular}

ADLs (Activities of Daily Living).

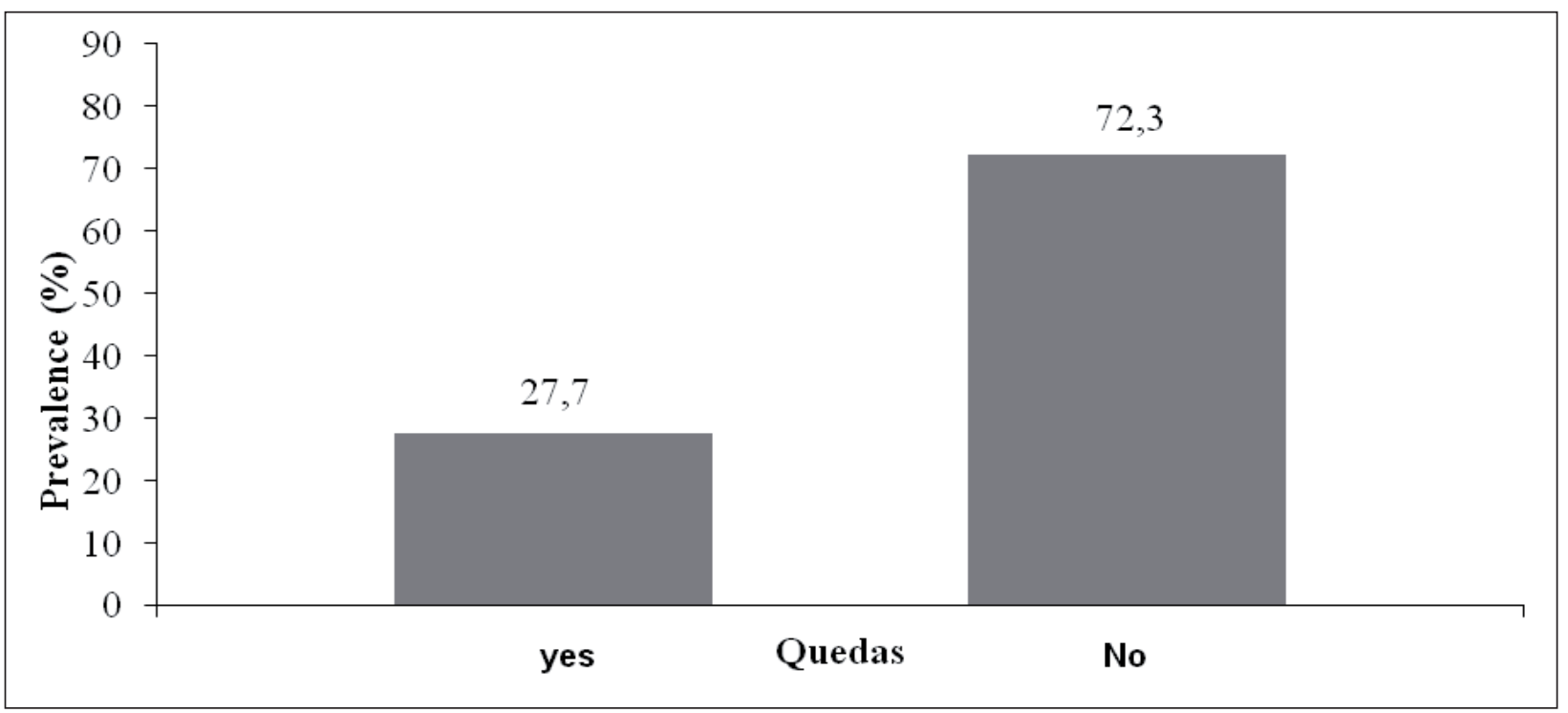

Figure 1 -Proportional distribution of elderly according to the occurrence of falls. Lafaiete CoutinhoBahia, Brazil, 2011 
Table 2 shows the results of the rough analysis of the relationship between falls and the adjustment variables. It is possible to observe that falls weren't associated with any variables; how- ever gender, marital status, physical activity and the number of chronic diseases reached sufficient statistical significance $(p \leq 0.20)$ to be included in the multiple analysis model.

Table 2 - Association between falls and adjustment variables. Lafaiete Coutinho-Bahia, Brazil, 2011

\begin{tabular}{|c|c|c|c|c|}
\hline Variables & Total & Fall (\%) & PR (CI95\%) & $\mathbf{p}$ \\
\hline \multicolumn{5}{|l|}{ Gender } \\
\hline Female & 56 & 19 (33.9) & $1.84(0.88-3.82)$ & 0.09 \\
\hline Male & 38 & $7(18.4)$ & 1 & \\
\hline \multicolumn{5}{|l|}{ Literate } \\
\hline Yes & 20 & $6(30.0)$ & 1 & 0.79 \\
\hline No & 74 & $20(27.0)$ & $0.90(0.41-1.96)$ & \\
\hline \multicolumn{5}{|l|}{ Marital status } \\
\hline In a stable union & 42 & $8(19.0)$ & 1 & 0.09 \\
\hline Not in a stable union & 52 & $18(34.6)$ & $1.81(0.90-3.66)$ & \\
\hline \multicolumn{5}{|c|}{ Per capita Income ( $R \$)$} \\
\hline$\leq 255.00$ & 39 & $12(30.8)$ & $1.23(0.42-3.59)$ & 0.92 \\
\hline $255.00-510.00$ & 37 & $11(29.7)$ & $1.18(0.40-3.53)$ & \\
\hline$>510.00$ & 12 & $3(25.0)$ & 1 & \\
\hline \multicolumn{5}{|c|}{ Participation in religious activities } \\
\hline Yes & 87 & $25(28.7)$ & 1 & 0.67 \\
\hline No & 5 & $1(20.0)$ & $0.69(0.12-3.78)$ & \\
\hline \multicolumn{5}{|l|}{ Physical activity } \\
\hline Active & 24 & $4(16.7)$ & 1 & 0.14 \\
\hline Insufficiently active & 68 & $22(32.4)$ & $1.94(0.79-4.73)$ & \\
\hline \multicolumn{5}{|c|}{ Number of chronic diseases } \\
\hline None & 15 & 1(6.7) & 1 & \\
\hline One & 30 & $10(33.3)$ & $5.00(0.98-25.41)$ & 0.13 \\
\hline Two or more & 48 & $15(31.3)$ & $4.68(0.94-23.18)$ & \\
\hline \multicolumn{5}{|l|}{ ADLs* } \\
\hline Independent & 74 & $16(21.6)$ & 1 & 0.004 \\
\hline Dependent & 18 & $10(55.6)$ & $2.56(1.34-4.91)$ & \\
\hline
\end{tabular}

ADLs (Activities of Daily Living).

Table 3 shows the results of the rough analysis and the analysis adjusted for falls and ADLs. Results showed a strong association between falls and functional capacity, even after adjustment for sociodemographic factors, physical activity and chronic diseases. The multiple regression model suggests that, independent of gender, age, marital status, physical activity level and number of chronic diseases, the probability of falling in a 12-month period is approximately twice as high $(\mathrm{PR}=2.08)$ among those elderly dependent for ADLs than among the independent elderly.

Table 3 - Rough and adjusted prevalence ratios for the occurrence of falls in the last 12 months and ADLs. Lafaiete Coutinho-Bahia, Brazil, 2011

\begin{tabular}{lcccc}
\hline \multicolumn{1}{c}{ Variable } & \multicolumn{3}{c}{ Falls } \\
\cline { 2 - 5 } & $\mathbf{P R}_{\text {rough }}(\mathbf{C l 9 5 \% )}$ & $\mathbf{p}$ & $\mathbf{P R}_{\text {adjusted }}^{*}(\mathbf{C l 9 5 \% )}$ & $\mathbf{p}$ \\
\hline Activities of daily living & 1 & & 1 & \\
Independent & & & 1 & \\
Dependent & $2.56(1.34-4.91)$ & 0.004 & $2.08(1.17-3.70)$ & 0.01 \\
\hline
\end{tabular}

* Adjusted for gender, marital status, physical activity level and number of chronic diseases. 


\section{DISCUSSION}

The growth of the elderly population has been occurring rapidly. Scientific production regarding this population group is still incipient, however, and has not been following with the same speed of growth. This is the first population study based on home living carried out exclusively with Brazilian seniors 80 years of age or over, verifying the association between falls and functional capacity.

In a cohort of 1667 elderly individuals aged 65 years or over, dwelling in a community and showing results for individuals aged 75 to 84 years, it was verified that for the elderly who require help with daily activities, the probability of falling was 14 times higher when compared to independent individuals of the same age. ${ }^{17}$

Another investigation verified that around $30 \%$ of the Brazilian elderly suffer at least one fall per year. ${ }^{4}$ A research with a sample composed of 4,003 individuals aged 65 years or over in seven Brazilian states showed a prevalence of falls of $34.8 \% .^{18}$ A significantly higher value was found in Brasilia (51.8\%), but the sample for this study was comprised of female seniors only. ${ }^{19}$ Some of these publications categorized the elderly by age group, including those aged 80 years of age or over; however, none of them specifically deal with the oldest old.

The prevalence of falls $(27.7 \%)$ found here is similar to values found in international research, such as the one conducted in Turkey with 3,231 community-dwelling citizens 60 years of age or over $(31.9 \%)^{21}$ and in the United States (USA) with seniors 70 years of age or older (35\%). ${ }^{21}$ However, research conducted in Spain with seniors 65 years of age or over ${ }^{22}$ and in Great Britain with female seniors aged between 60 and 79 years ${ }^{23}$ show a lower prevalence $(17.9 \%$ and $16.9 \%$, respectively).

In this perspective, the present study confirms the magnitude of falls as a public health phenomenon that, because of their impact on the lives of the elderly and of their families, as well as on the healthcare system, represent significant economic and social costs.

The functional dependency in terms of ADLs observed by other authors varied from $15 \%{ }^{24}$ to $25 \%{ }^{25}$ among the elderly over the age of 60 years, to $45 \%{ }^{26}$ among the elderly 80 years of age or older. The differing proportion of functional dependency of older seniors in the present study can be justi- fied by differences between the methodological criteria, such as the study population (rural area) and the instrument that was used.

After the age of 80 , even with a relatively healthy aging process, some degree of physiological compromise is expected in regards to the capacity for performing ADLs. The frequency and intensity of this compromise varies, depending on the general health conditions throughout life and the lifestyle in each historical, social, economic and cultural context. ${ }^{27}$

With aging, the human body enters a process of physiological decline, with decreasing bone density and muscular mass, postural instability and lack of balance. ${ }^{28-30}$ Thus, functional capacity tends to decrease and these changes can lead to a higher vulnerability and/or tendency to fall. In this study, a high magnitude association between falls and functional capacity was identified and this result, taking into account the methodological differences, is similar to the results observed in other studies conducted in Brazil. 6,17,31-33

Evidence suggests that the risk of falls in the elderly can be reduced through integrated actions. In an intervention study with 301 communitydwelling seniors aged 70 or over enrolled in a health organization in Connecticut (USA), ${ }^{34}$ it was concluded that many risk factors for falls also contribute to immobility and functional decline. The interventions, conducted by nurses and physical therapists, were related to: environmental changes, behavioral recommendations, education and revisions in the use of medications, walking and transfer training and strengthening, resistance and balance exercises. There was a significant difference $(p=0.04)$ between the intervention group and the control group in regards to the proportion of elderly who suffered falls (35\% for the first group and $47 \%$ for the second). Moreover, an increase in functional capacity was also noted, which possibly contributed to the decrease in the frequency of falls.

A study conducted with 72 seniors in a lowincome community in Rio de Janeiro verified that the fear of falling became part of their life and was referenced by $88.5 \%$ of the 26 seniors who had suffered some consequence from a previous fall. Among those, the abandonment of certain activities $(26.9 \%)$, a change in habits $(23.1 \%)$ and immobilization (19\%) were of greatest significance. ${ }^{35}$

After a fall, there is not only a fear of falling again, but also a fear of new falls, hospitaliza- 
tion, immobilization, a decline in health and/or a fear of dependency on others for self-care. This fear can cause serious emotional, psychological and social changes, such as: loss of autonomy and independence regarding ADLs, a decrease in social activities, and a feeling of weakness and insecurity. ${ }^{36}$ Moreover, when the elderly fall, there is a tendency to decrease their daily activities for fear of exposing them to a new fall, or as a protective measure by families or care providers.

In addition to the feeling of fear that can justify the association between falls and functional capacity, it is known that changes in muscular strength in the elderly, which affects mainly the muscles of the lower limbs ${ }^{37}$, can affect balance and the performance of activities of daily living. Because of these changes, the probability of falls associated with lower functional capacity is increased.

It is observed in the literature that the decrease in functional capacity is presented either as a causative factor or as consequence of the falls. It is also worth noting, as a limitation of the present study, that the complexity of the process of determining the occurrence of falls, the functional capacity and the limitation of cross-sectional studies makes it impossible to identify the temporal precedence of the studied factors, compromising the evidence of causal relation.

Regarding the interpretation of the results, data derived from the Katz scale are selfreferenced and, thus, can suffer the influence of cognitive functions, culture, language used and education. On the other hand, the self-referred measures provide information about the functional limitations of the elderly within a defined social context. It is also noted that data collection at the seniors' homes brings higher reliability to the information.

\section{CONCLUSION}

It is suggested that the study of factors associated with the occurrence of falls in the elderly, which is considered a serious public health problem, can result in positive attention and mobilization to create policies of health prevention that could delay the development of disease and incapacities. Thus, intrinsic characteristics of the individual, such as their capacity for ADLs, should be considered in programs for the prevention of falls, even if they are conducted with individuals in more advanced stages of life. This age group does not only represent different biological characteristics from other individuals, but also presents unique psychological, cultural, socioeconomic and epidemiological characteristics that should be individually studied.

Looking at the study results, it can be concluded that there is an association between the occurrence of falls and functional dependency in the activities of daily living for the communitydwelling oldest old.

\section{REFERENCES}

1. Instituto Brasileiro de Geografia e Estatística. Projeção da população do Brasil por sexo e idade, 1980-2050: revisão 2008. [página da Internet]. Rio de Janeiro (RJ): IBGE; 2008 [acesso 2011 Jan 4]. Disponível em: http://www.ibge.gov. br/home/estatística /populacao/projecao_da_ populacao/2008/projecao.pdf

2. Tinetti ME, Speechley M, Ginter SF. Risk factors for falls among elderly persons living in the community. N Engl J Med. 1988 Dez; 319(26):1701-7.

3. Wolinsky FD, Johnson RJ, Fitzgerald JF. Falling, health status, and the use of health services by older adults: a prospective study. Med Care. 1992 Jul; 30(7):587-97.

4. Perracini MR, Ramos LR. Fatores associados a quedas em uma coorte de idosos residentes na comunidade. Rev Saúde Pública. 2002 Dez; 6(6):709-16.

5. Duthie, EH, Katz PR, organizadores. Geriatria prática. $3^{\mathrm{a}}$ ed. Rio de Janeiro (RJ): Revinter 2002. p. 193-200.

6. Fabrício SCC, Rodrigues RAP, Costa Junior ML. Causas e conseqüências de quedas de idosos atendidos em hospital público. Rev Saúde Pública. 2004 Fev; 38(1): 93-9.

7. Ministério da Saúde (BR). Secretaria de Atenção à Saúde. Departamento de Atenção Básica. Envelhecimento e saúde da pessoa idosa. Série A. Normas e Manuais Técnicos. Cadernos de Atenção Básica; n. 19.Brasília (DF): MS; 2007.

8. Alves LC, Leimann BCQ, Vasconcelos MEL, Carvalho MS, Vasconcelos AGG, Fonseca TCO, et al. A influência das doenças crônicas na capacidade funcional dos idosos do Município de São Paulo, Brasil. Cad Saúde Pública. 2007 Ago; 23(8): 1924-1930.

9. Albala C, Lebrão ML, Díaz EML, Ham-Chande R, Hennis AJ, Palloni A, et al. Encuesta Salud, Bienestar y Envejecimiento (SABE): metodología de la encuesta y perfil de la población estudiada. Rev Panam Salud Publica. 2005 Jun; 17(5/6): 307-22. 
10. Benedetti TB, Mazo GZ, Barros MVG. Aplicação do questionário internacional de atividades físicas (IPAQ) para avaliação do nível de atividades físicas de mulheres idosas: validade concorrente e reprodutibilidade teste-reteste. Rev Bras Ciência Mov. 2004 Jan-Mar; 12(1): 25-34.

11. Icaza MC, Albala C. Projeto SABE. Minimental State Examination (MMSE) del estudio de dementia em Chile: análisis estísticos. Brasília (DF): OPAS; 1999. p. 1-18.

12. Pfeffer RI, Kurosaki TT, Harrah CH Jr, Chance JM, Filos S. Measurement of functional activities in older adults in the community. J Gerontol. 1982 May; 37(3):323-9.

13. Katz S, Ford AB, Moskowitz RW, Jackson BA, Jaffe MW. The index of ADL: a standardized measure of biological and psychosocial function. JAMA 1963 Sep; 185(12):914-9.

14. Duarte $Y A O$, Andrade CL, Lebrão ML. O índex de Katz na avaliação da funcionalidade dos idosos. Rev Esc Enferm USP. 2007 Ago; 41(2):317-25.

15. Hallal PC, Victora CG, Wells JC, Lima RC. Physical inactivity: prevalence and associated variables in Brazilian adults. Med Sci Sports Exerc. 2003 Nov; 35(11):1894-900.

16. Coutinho LMS, Scazufca M, Menezes PR. Métodos para estimar a razão de prevalência em estudos de corte transversal. Rev Saúde Pública. 2008 Dez; 42(6):992-8.

17. Perracini MR. Fatores associados a quedas em uma coorte de idosos residentes no município de São Paulo [tese]. São Paulo: Universidade Federal de São Paulo; Escola Paulista de Medicina; 2000.

18. Siqueira FV, Facchini LA, Piccini RX, Tomasi E, Thumé E, Silveira DS, et al. Prevalência de quedas em idosos e fatores associados. Rev Saúde Pública. 2007 Out; 41(5):749-56.

19. Gai J, Gomes L, Nóbrega OT, Rodrigues MP. Fatores associados a quedas em mulheres idosas residentes na comunidade. Rev Assoc Med Bras. 2010 Mar; 56(3):327-32.

20. Evci ED, Ergin F, Beser E. Home accidents in the elderly in Turkey. Tohoku J Exp Med. 2006 Aug; 209(4):291-301.

21. Campbell AJ, Robertson MC, Gardner MM, Norton RN, Tilyard MW, Buchner DM. Randomised controlled trial of a general practice programme of home based exercise to prevent falls in elderly women. Br Med J. 1997 Out 25; 315(7115):1065-9.

22. Sanchez ES, Guiteras PB, Llanes JM, Bustos AM, Beneyto VM, Gaju RT. Falls in the elderly: knowing to act. Aten Primaria. 2004 Set 15; 34(4):186-91.

23. Lawlor DA, Patel R, Ebrahim S. Association between falls in elderly women and chronic diseases and drug use: cross sectional study. BMJ. 2003 Set 27; 327(7417):712-7.
24. Lima-Costa MF, Barreto SM, Giatti L. Condições de saúde, capacidade funcional, uso de serviços de saúde e gastos com medicamentos da população idosa brasileira: um estudo descritivo baseado na Pesquisa Nacional por Amostra de Domicílios. Cad Saúde Pública. 2003 Mai-Jun; 19(3):735-43.

25. Roriz-Cruz M, Rosset I, Wada T, Sakagami T, Ishine M, Roriz-Filho JS, et al. Stroke-independent association between methabolic syndrome and functional dependence, depression and low quality of life in elderly community-dwelling Brazilian people. J Am Geriatr Soc. 2007 Mar; 55(3):374-82.

26. Morais EP. Envelhecimento no meio rural: condições de vida, saúde e apoio dos idosos mais velhos de Encruzilhada do Sul-RS [tese]. Ribeirão Preto (SP): Universidade de São Paulo. Escola de Enfermagem de Ribeirão Preto; 2007.

27. Costa EC, Nakatani AYK, Bachion MM. Capacidade de idosos da comunidade para desenvolver Atividades de Vida Diária e Atividades Instrumentais de Vida Diária. Acta Paul Enferm. 2006 Jan-Mar; 19(1):43-8.

28. Monteiro CR, Faro ACM. Avaliação funcional de idoso vítima de fraturas na hospitalização e no domicílio. Rev Esc Enferm USP. 2010Set; 44(3):719-24.

29. Aveiro MC, Navega MT, Granito RN, Rennó ACM, Oishi J. Efeitos de um programa de atividade física no equilíbrio e na força muscular do quadríceps em mulheres osteoporóticas visando uma melhoria na qualidade de vida. Rev Bras. Ciênc. Mov. 2004 Set; 12(3):33-8.

30. Nascimento BN, Duarte BV, Antonini DG, Borges SM. Risco para quedas em idosos da comunidade: relação entre tendência referida e susceptibilidade para quedas com o uso do teste clínico de interação sensorial e equilíbrio. Rev Bras Clin Med. 2009 Mar; 7: 95-9.

31. Cianciarullo TI, Gualda DMR, Silva GTRS, Cunha ICKO. Saúde na família e na comunidade. São Paulo (SP): Robe Editorial; 2002.

32. Rosa TEC, Benício MHD, Latorre MRDO, Ramos LR. Fatores determinantes da capacidade funcional entre idosos. Rev Saúde Pública. 2003 Fev; 37(1):40-8.

33. Nunes MCR, Ribeiro RCL, Rosado LEFPL, Franceschini SC. Influência das características sociodemográficas e epidemiológicas na capacidade funcional de idosos residentes em Ubá, Minas Gerais. Rev Bras Fisioter. 2009 Nov; 13(5):376-82.

34. Tinetti ME, Baker DI, Mcavay G, Claus EB, Garrett $\mathrm{P}$, Gottschalk M, et al. A multifactorial intervention to reduce the risk of falling among elderly people living in the community. N Engl J Med. 1994 Set; 331(13):821-7.

35. Ribeiro AP, Souza ER, Atie S, Souza AC, Schilithz AO. A influência das quedas na qualidade de vida de idosos. Ciênc. Saúde Coletiva. 2008 Jul-Ago; 13(4):1265-73. 
36. Beck AP, Antes DL, Meurer ST, Benedetti TRB, Lopes MA. Fatores associados às quedas entre idosos praticantes de atividades físicas. Texto Contexto Enferm. 2011 Abr-Jun; 20(2):280-6.
37. Frontera WR, Hughes VA, Fielding RA, Fiatarone MA; Evans WJ, Roubenoff R. Aging of skeletal muscle: a 12 - year longitudinal study. J Appl Physiol. 2000 Apr; 88: 1321-6.
Correspondence: Núcleo de Estudos em Epidemiologia do Envelhecimento

Universidade Estadual do Sudoeste da Bahia - Departamento de Saúde

Av. José Moreira Sobrinho, S/N,

45206-190 - Jequiezinho, Jequié, BA, Braszil

E-mail: thaisbrito03@yahoo.com.br
Received: August 26, 2011 Approved: September 18, 2012 